\title{
Pompeo Caccini and Euridice: New Biographical Notes
}

\author{
TIMOTHY J. MCGEE
}

\section{$I_{n}$} surrounding the performance of the first opera Jacopo Peri's Euridice in Florence on October 6, 1600, for the wedding of Maria de' Medici and Henry IV of France. He included a list of singers known to have performed the various roles at the premier and at the second production which probably took place shortly afterwards. ${ }^{1}$ Not all of the performers were known, however, and one that Palisca could not name was La Tragedia, the singer of the Prologue. He speculated that the part may have been sung by the same man who sang in the second production, a singer known only as "Giovannino del Sig[nor] Emilio [dei Cavalieri]," but as we shall see, that is not correct. Recently discovered documents reveal not only the name of the first singer of the Prologue, but they tell us of Pompeo Caccini's involvement in the first opera and a bit about vocal teaching methods in the early Baroque. Further, while giving us new information about the biography of Giulio Caccini's oldest child, they also provide a very clear impression of the social status of courtly musicians at the end of the sixteenth century.

My story is a curious one, dealing with the mores of both the ruling class and their servants. Some of it begins at the level of gossip and it does not show off the characters in the best possible light. On the other hand, it does add important information on a number of subjects, and so I beg the readers' indulgence for unearthing a bit of historical dirt to tell my tale of music, love, marriage, and power.

Pompeo Caccini, the only son of Giulio Romano, enjoyed a rather diverse career in the arts as singer, teacher, artist, and set designer. His accomplishments are overshadowed now in music history, as they were during his own lifetime, by the extraordinary singing talent first of his father and then of his sister Francesca, but what little is known suggests that he was a competent as well as a versatile artist and perhaps even a minor luminary 
during the early decades of the seventeenth century. The newly-discovered documents reported here now connect him intimately with Euridice and lead to a revision of some of the previously believed ideas about his life. I will begin my story where I first encountered it-in the records of petitions to the Florence civic magistrates, the "Otto di Guardia." On the 27th of February 1601 the following petition was filed (Document I):

\section{Most Serene Grand Duke}

Camilla of Piero Mazziere, relative of Don Stefano Buonsignori, most humble servant of Your Serene Highness, a poor woman with six daughters, humbly turning to your mercy desiring that he render justice regarding the great wrong and dishonour done to her by Pompeo, bastard son of Giulio Romano. This came about because he had frequented her house for a long time in order to teach her daughter Ginevra, called "l'Azzurina," to sing the prologue of the play, and she permitted such frequenting of her house in order to please masters Giacopo Corsi and Ottavio Rinuccini, who had requested the assignment of this young man to teach her, with the hope of enabling her to acquire a dowry in order to marry her off, and primarily in order to serve the Most Christian Queen of France and Your Highness as was her duty. He [Pompeo] had the impudence one day, lurking until the abovementioned young girl was home alone, to open the door with a false key, or other tool, and violently raped and impregnated her. The said supplicant [Camilla] kept this quiet because Pompeo gave his word to the gentleman, and had it put in writing and promised to take her [Ginevra] as his wife when the play was over. Later, however, when he was detained by his father and sent away so that the marriage would not take place, she [Camilla] had recourse to the Magistrate of the Otto [di Guardia], who issued a sentence that was too easy and pleasant for the young man and was not a condemnation equal to the offense, having condemned him to pay 75 scudi only and without adding any other penalty that was applicable according to the statutes of the commune of Florence and the common laws. Therefore she appeals to Your Highness that you deign to render justice to her (as is your wont), and that you not permit that Ginevra and the other poor girls [her sisters] to miserably lose their honour,-nor [that] her brother and brother-in-law, who are not used to giving or receiving any wrong, even if by resorting to some illegal remedy, [lose their honour]-nor that she the supplicant [lose her honour]. [The supplicant], being of most honourable parents who have always faithfully served and continue to serve the most honourable house of Medici, seeing them wrongfully dishonoured, appeals to the sumtuous tribunal ...27 February 1601.

Francesco Buoninsegni [Clerk of Court] 
On the reverse side of the accusation Buoninsegni has written the verdict along with a summary of the evidence which gives the same information but with a slightly different emphasis (Doc. II):

The supplicant Cammilla brought action against Pompeo, natural son of Giulio Romano, [alleging] that Pompeo, who frequented her house for the purpose of teaching her daughter Ginevra to sing for the prologue of the play, and, full of desire for her and pretending to want her for his wife, one day entered the house when her mother was not present, and with flattery and promises and partly by force, used her carnally and left her pregnant. And in his [Pompeo's] absence the magistrate condemned him the 12th day of February, 1601, for rape, with a fine of 100 lire, and a dowry to Ginevra of 75 scudi, with the condition that should he take her for his wife, he is to consider himself free of this payment. Now, appearing to the mother that this sentence is not sufficient to recover the honour taken from her, and desiring that the marriage take place, asks that such punishment be given him that will force him to observe what he promised if he wishes to be pardoned and that a deadline be fixed [for the wedding]. At the chancery, 15 March 1600.

Other depositions in the same file substantiate the points made above and shed a bit more light on young Pompeo, his activities and his involvement with Ginevra. On the 12th of March, a few weeks after the document above was written, the following testimony was given (Doc. III):

I, Gian Jacopo Cini, swear that a few months ago, having been continually in the house of Mona Cammilla of Piero Mazziere on account of the silk [trade], I became acquainted with her and her most honourable daughters, and because of this I frequently saw Pompeo Caccini there, and I asked why. Mona Cammilla replied that he came because Signor Jocomo Corsi and Signor Ottavio Rinuccini had ordered him [comissioned him?] to come to teach her daughter Ginevra to sing the prologue of the play and also because he had promised and had put in writing to marry her after the performance. And at the time of the marriage of the most Christian Queen of France, I saw on the finger of the abovementioned Ginevra a ring with three pearls, and I asked her if she had not kept some wedding candy for $\mathrm{me}^{2}{ }^{2}$ imagining that she had become betrothed, and she told me that Pompeo had given it [the ring] to her, but would not have the wedding until the play was finished. I swear also how at the same time I heard from the mouth of Pompeo, who one day, while talking with me during a 'Carda' game in Campaccio, said that for fear of his father, who was annoyed at them because she was reciting the prologue against his wishes, and also in order to set 
himself up more comfortably, he was not able to marry her after the play was finished.

The problem Pompeo was having with his father and the meaning of the statement "to set himself up more comfortably" becomes clearer in yet another deposition given by a cleric of the church of Santa Maria del Fiore (Doc. IV). This document also suggests that Pompeo probably did have honourable intentions but could not convince his father:

I, Michele di Jacopo Date, cleric of Florence, swear that a few months ago I went to the shop of Cigoli where Pompeo Caccini, son of Giulio Romano, worked, in order to ask from him two paintings of towns which he had agreed to do for me. He begged me to intercede with Madame Camilla, wife of Piero Mazziere, to have her agree to wait a year to 18 months more before revealing the marriage contract that he had made with her daughter, and this delay was in order for him to earn enough to acquire a room, which he would not be able to do if he were thrown out of his home by his father, which would happen if his father knew that he had taken a wife without consent. And so I went to Madonna Cammilla, who provided many reasons for which she could not wait this much time. I swear this to be the truth written by my hand this day in Florence.

Finally, on the 26 of June, three months after the above testamony, a letter from Giulio Caccini to the court concludes the affair. He acknowldges his son's blame in the matter but attempts to avoid the fine. The Caccinis do agree to pay the dowry while at the same time implying that there was little hope that Pompeo was going to marry Ginevra (Doc. V).

\section{Serene Grand Duke}

Giulio Caccini, most humble servant and vassal of your Highness, with all due respect, points out how in the past months his son Pompeo was condemned in absentia by the Magistrate of the Otto [di Guardia], and fined 100 lire to be paid to the Fisco [treasury] and 75 scudi to be deposited and paid as a dowry for Ginevra, known as l'Azzurina. Now, desiring of the repatriation of this son, begs Your Highness to excuse him, notwithstanding the condemnation in absentia, from the fine of 100 lire to be submitted to the treasury, since he is prepared to pay the 75 scudi to Ginevra, called 'l' Azzurina,' when she will marry in accordance with the abovementioned magistrate. Concerning all this he will be held perpetually obliged to your Serene Highness and will ever after pray God to keep you most happy. ${ }^{3}$ 
I was not able to ascertain with certainty what did happened to Ginevra, but other documents provide at least circumstantial evidence that in spite of what is stated and implied in the above documents, Pompeo did eventually marry her. In a letter of December 1604 from Ottavio Rinuccini in Paris to the Grand Duchess in Florence there is reference to a Ginevra who received a gift from the Queen of France (Maria de' Medici), (Doc. VI). The letter does not say what Ginevra did to merit the gift, but the statement appears in conjunction with a comment about Giulio Caccini's concert of women's voices during the well-known visit of Giulio and his family to the French court, and the implication is that Ginevra was also a singer, perhaps even a member of Giulio's group: ${ }^{4}$

\section{Serene Grand Duchess}

... Signora Ginevra has been recieved by her majesty the Queen with a show of happiness and of extraordinary satisfaction, and just today [the Queen] has given her a beautiful pair of diamond earrings, caressing and favoring her without cease. The concert of Giulio [Caccini] has pleased the King so much that the music lasted until an hour past midnight, and for this reason I bow humbly and pray to God for your every happiness.

And in a letter to the Grand Duchess from Camillo Rinuccini in February of 1608 there is a reference to the "wife of Pompeo" being sent to Mantua to help in a performance (Doc. VII):

When your Serene Highness left Florence you asked me to write to Mantova to Signor Ottavio Rinuccini, to make excuses again to those princes about Your Highness' inability to agree for the women of Giulio Romano [i.e. the concerto delle donne] partly because they are already involved in celebrations here, and partly because of their delicate health, that to travel in unfavourable weather would threaten that they would not be able to serve either here or there, and to say that, if Their Highnesses wished to supplement the number of their singers, Your Highness would send them Livia and Pompeo's wife, who were not yet involved [in the Florence celebration] and would better tolerate the trip. I wrote immediately as I was obliged to and received a reply on 19 January in these words: he offered the mentioned singers together with the excuse for the impossibility of sending the other [singers]. Tell your Lady that she may know that Their Highnesses are satisfied and that I have performed my duty as I was obliged...

The Mantuan performance referred to above would undoubtedly be Arianna, Claudio Monteverdi's second opera, on the text by Ottavio Rinnucini, and Tim Carter has concluded that "Pompeo's wife" probably 
performed the role of Venus. ${ }^{5}$ The letter suggests that Pompeo's wife was of such calibre as a singer that she would be acceptable for performance at a court known for its high musical quality. My suspicion that this unnamed wife was probably Ginevra is supported by the fact that once again the negotiations involved Ottavio Rinuccini, and he has shown obvious interest in Ginevra in the past both in his request for her to sing in the 1600 production and in his 1604 letter which singles her out alone for comment of all the singers with the Caccini entourage in Paris. But although the two letters hint that Pompeo had eventually married Ginevra, no documents were found that state clearly that this was so.

As to the importance of the above information to music history, the "Comedia" mentioned in documents I-IV is surely Euridice with text by Ottavio Rinuccini and music by Jacopo Peri, produced by Jacopo Corsi. ${ }^{6}$ And thus we can conclude that the singer of the Prologue at the first performance was one Ginevra Mazziere, known by the professional name of "l'Azzurina." The cast list provided by Palisca can now be amended by the addition of her name (see Table I). She did not, however, sing the second production whereas Pompeo sang in the second production but is not listed in the first.

Table I:

CAST OF EURIDICE ${ }^{7}$

Roles

La Tragedia

Euridice

Orfeo

Arcetro

Tirsi

Aminta

Dafne

Venere

Choro di Ninfe

e pastori

Plutone

Proserpina

Radamanto

Caronte
October 6, 1600

Ginevra Mazziere

[Caccini dependent]

Jacopo Peri

Antonio Brandi

Francesco Rasi

Jacopo Giusti

[Caccini dependents]

Melchior Palandrotti

Pienza

[same as Venus]

Piero Mon

[Priest from the church of the Annunciation] 
In two of the documents from the Magistrates' court the names of Jacopo Corsi and Ottavio Rinuccini are given in connection with Euridice, but neither one mentions the composer of the music-Jacopo Peri. This is not an unusual occurrence in sixteenth- and seventeenth-century documents where the authors of texts of various musical productions are mentioned while the name of the composer is often omitted. We know from several sources that Corsi and Rinuccini had collaborated as early as 1594 on the dramatic pastoral Dafne, for which Peri was also invited to contribute music. ${ }^{8}$ They must have considered Peri's work to have been quite satisfactory, and the omission of his name by various chroniclers of the time is probably not to be construed as a judgement of the value of his music. The reason is most likely a reflection of the different social levels to which the men belonged; Corsi and Rinuccini were both respected Florentine noblemen, whereas Peri was not. On an artistic level his contribution was probably considered to be as important as that of the others, but in the above-quoted documents and in several other accounts of the first opera, it was the names of the noblemen that showed the relative importance of the undertaking. ${ }^{9}$ Additional evidence of Peri's lack of status and power, and perhaps an additional reason he was not cited as composer, is reflected in the actual first performance, at which not all of the music performed was by him.

In his foreword to the printed version of Euridice, Peri admits that, although he composed all of the music in that published copy, that was not what was sung for the first performance. ${ }^{10}$ On that occasion Giulio Caccini wrote his own music for all parts sung by his dependents-that is, the parts of Euridice, some of the shepherds, the nymphs, and several of the choruses. To recreate what was actually sung on that occasion, therefore, we must also look at the printed version of Caccini's setting of the opera for the parts sung by people under his direction. ${ }^{11}$ Palisca points out that Peri appears to have written the lion's share, setting 658 lines of the poetry to only 132 by Caccini. After realizing now that Caccini's son taught the part of $\mathrm{La}$ Tragedia to Ginevra for the first performance, we might suspect that she sang the version written by Caccini, and that Peri overlooked this item when making up his list. Should this be true, there would actually be very little change in the proportions of the music written by the two composers, subtracting 28 lines from Peri's total and adding them to Caccini's.

The Prologue is actually quite simple as written, no matter which version is considered-either 13 or 14 measures of music (both versions have been provided in Example I for comparison). What Pompeo was to teach Ginevra, therefore, must have been his father's particular style of expression 

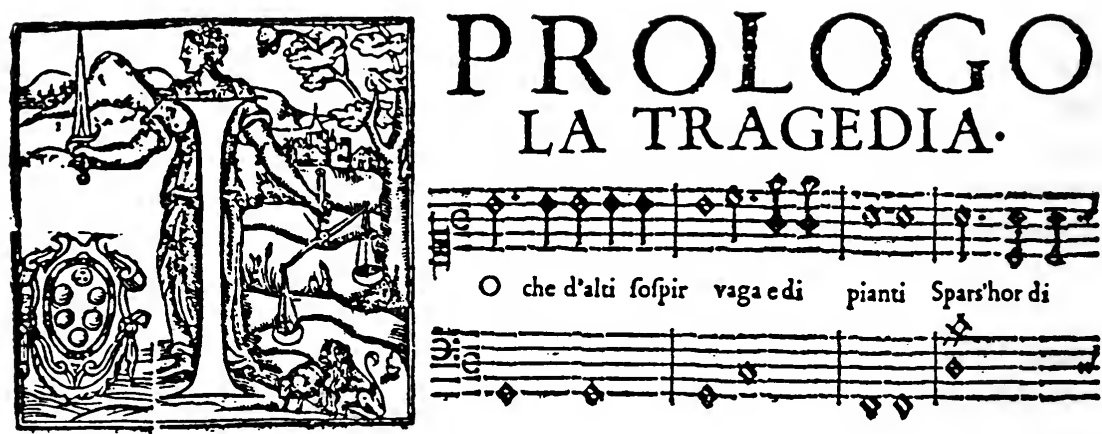

O che d'alci fofpir ragaedi pianti Sparshordi
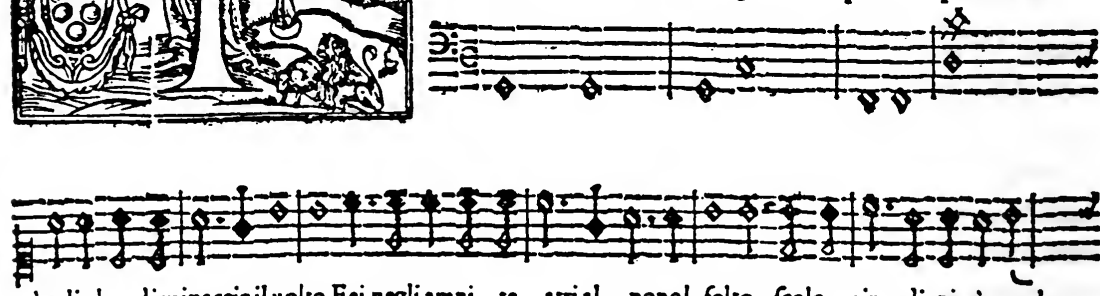
doglia hordiminaccieilvolto Feinegliampi te atrial popol folto fcolo rir di pieta vol

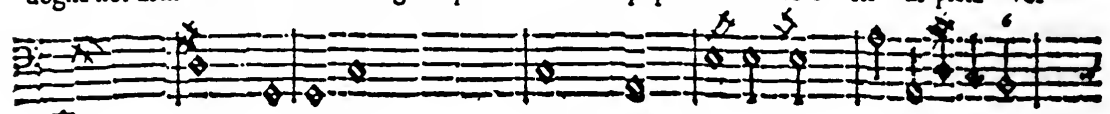
$\$$

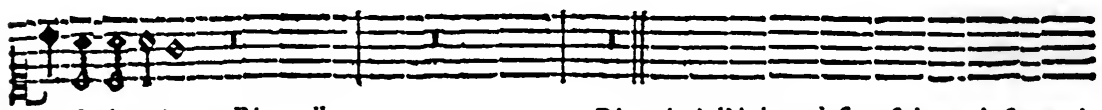

tiefembianti. Ritornello

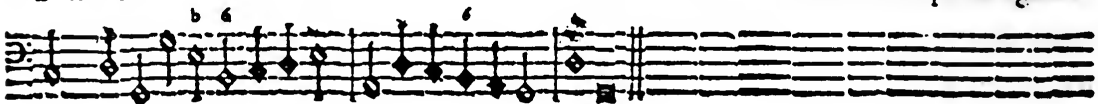

Ricomincia l'A ria medefima fu le parole feguenti.

3

Non fangue fparfo dinnocenti vene, Non ciglia fpente di Tiranno infano, Spertacolo infelice al guardo vmano Canto fu mefte, e lagrimofe feene.

$$
3
$$

Lungi via lungi pur da regij tetti Simolacri funefti ombre d'affanni E co imefti coturni, ei forchipanni' Cangio e desto ne i cor piu dolci afferai 4

Hor s'auuerra, che le cangiate forme Non fenz'al wo fupor la terra ammiri Ial ch'ogni alma gencil ch'A pollo infpiri Del mio douo cammun calpeftilorme.
Voltro Regina fia cotanto alloro Qual forfe anco nô colfe Atene,o Roms Fregio non vil ful'onoraea chioma Fronda Febea fra due corone d'oro $\boldsymbol{c}$

Ial per roi tomo, e con fereno afpeto NeReali Imenei m'adorno anch'io, Efu corde piu liete il canto mio Tempro al nobile cor dolce dilet to. 7

Mentre Seana Real prepara intanto Alro diadema ond il bel crin fo fregi, Ei manti, e feggi de gli antichi Regi Del Iracio Orfeo darel'orecchia al canta. 

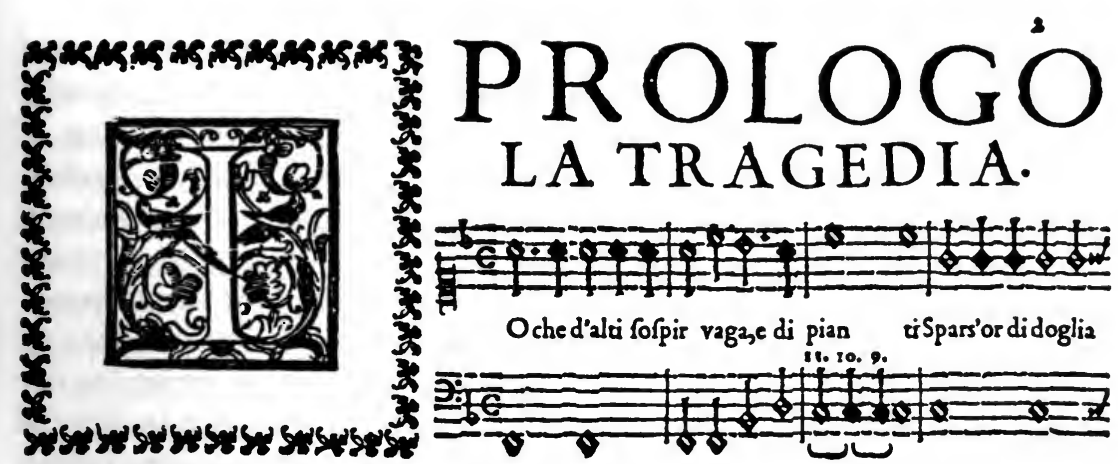

Oched'alui forpir vaga,e di pian tispars'or didoglia
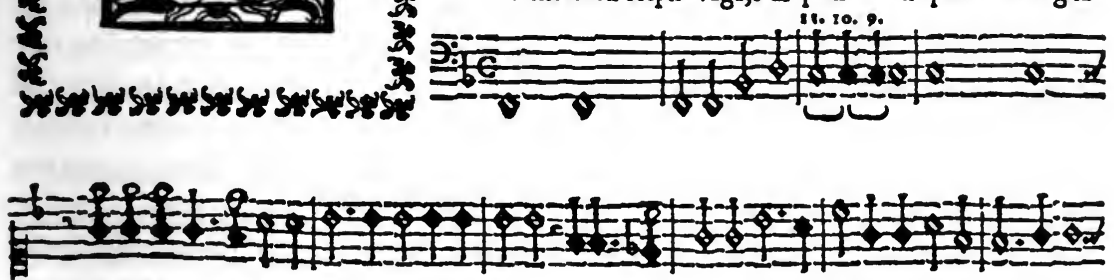

hor di minaccieil volto Feinegl'ampito atri alpopol folto Scolorir dipieti volri,e fembian-
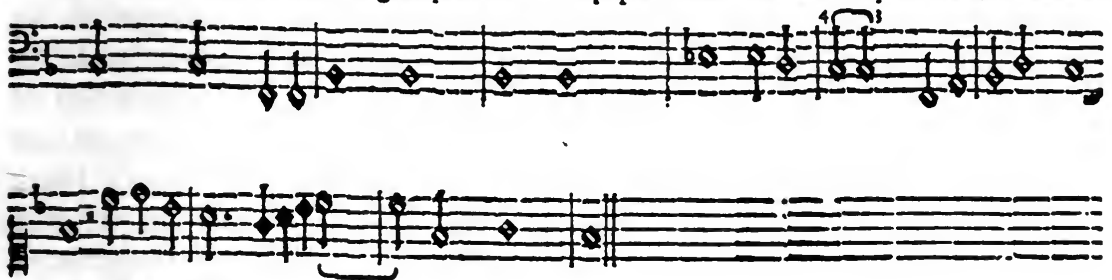

i. Ritorncllo.

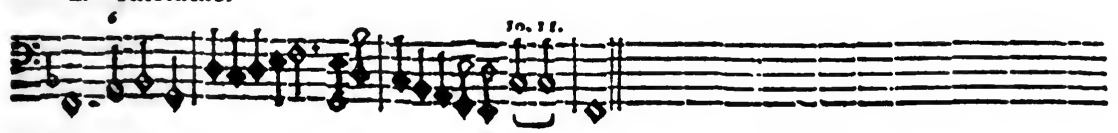

Non langue fparfod innocenti verte Non ciglia fpente di Tiranno infano Spettacolo infelice al guardo humano Canto fu mefte, elacrimofe feene.

\section{3}

Lingi via lungi pur da regij tetri Simulacri funefti, ombre d'affanni Ecco i mesti coturni, ei forchi panni Cangio, e defto ne icor piu dolci affecti

Hor s'auuerri, che le cangiate forme Non fenza alto ftupor la terra ammiri Tal ch'ogni alma gentil ch'Apollo inf́piri Del mio nouo cammin calpefti l'orme

\section{$s$}

Voftro Regina fia coranto alloro

Qual forf́c anco nó colle Atene, ò Roma

Fregro non vil fu lonorata chioma

Fronda Febea fra due coroned oro 6

Tal per roi torno, e con fereno a Spetto

NeReali Imenei m'adorno anch'io

E fu corde più liete il canto mio

Tempro al nobile cor dolce diletro 7

Mentre Senna Real prepara intanto Alto diadema, ondeil bel crin $\mathscr{l}$ fregi Ei manxi , e feggi degl'ancichi Regi Del Tracio Orfeo date l'orecchie al cáta 
and ornamentation as discussed and illustrated in Le Nuove Musiche of $1602 .^{12}$ According to the tenets of Giulio's new dramatic style, affects were to be added in order to demonstrate the words, and thus the amount of notes printed in the score and their apparent simplicity is quite misleading. The quasi-recitative appearance of the music was little more than a skeleton upon which the performer was to add the expressive dramatic garments, varying the embellishments to suit the words of each of the seven verses. This must have been a fairly difficult technique even at that time. One can assume that Ginevra had some performance background in order for her to have been specifically requested by Corsi and Rinuccini, and in fact she already had the professional name of "L'Azzurina." And yet to learn seven short verses of music she needed a private vocal coach who spent a sizable amount of time visiting her.

Facts in the testimony above cause us to review a popularly held evaluation of Giulio Caccini's personality vis-a-vis Euridice. That the singers Caccini trained sang his music has always been taken as evidence of his petulant personality; it was assumed that he forced this on Peri as a condition for allowing his singers to perform in the opera. And the publication of Caccini's version of the entire opera soon after the wedding-and prior to that of Peri - has been considered additional evidence of this irascibility. ${ }^{13}$ There is no doubt that Caccini had a strong and often abrasive personality, and that an intense rivalry existed between Caccini and Peri, but perhaps we have presumed too much conirol to have been in the hands of the musicians. Corsi and Rinuccini decided on Ginevra as the performer of the prologue, and even became involved to the point of choosing her vocal coach, indicating the level of decision-making they reserved to themselves. It is therefore entirely possible that the choice of the remainder of the cast was also theirs, and that the use of Caccini's settings for certain portions of the first performance was also at their request. This would not completely change our impression of Giulio Caccini's character, but in this case we are probably not justified in judging him so harshly.

The references to Pompeo as Giulio's “bastard son” in Camilla's letter (Doc. I), and as his "natural son" by the clerk of court (Doc. II), add a bit of confusion while at the same time contradicting currently held ideas about Pompco's parentage. In biographies of Giulio Caccini four children are identified. There is now sufficient documentary evidence for the birth dates of the three females, Francesca, (known professionally as "La Cecchina"), born on 18 September 1587, Settimia ("La Flora"), born on 27 September 
1591, both children of Giulio and his first wife Lucia, and Dianora, born 27 November 1599 to Giulio and his second wife, Margherita Benevoli della Scala. ${ }^{14}$ The birthdate of the only son, Pompeo, is less certain, but is usually given as between 1588 and $1590 .^{15}$

Nowhere is a source provided for the supposed birthdate of Pompeo, but we may strongly suspect that he was not born in 1588 or 1590 since he would have been only ten or twelve years old at the time he was found guilty in the paternity suit. Further, if he was the son of Giulio and Lucia, how could he be called illegitimate?

Documentation of Giulio and Lucia's wedding is found in an archival record that provides the information that on the 30th of June, 1584 Francesco de' Medici, Grand Duke of Florence, ordered Napoleone Cambi, the depositor general, to pay Giulio Caccini 1,000 scudi as a dowry for Lucia Garglialanti. ${ }^{16}$ This, or a date slightly before it, would appear to be the date of Caccini's wedding. ${ }^{17}$ To put the dowry amount in the proper perspective, according to the pay records of 1588 , Giulio was the highest paid member of the musical group in Florence, receiving 16 scudi per month, as compared to the more usual wage of 6 scudi paid to Jacopo Peri. ${ }^{18}$ Seen in this light, the dowry from the Grand Duke was extremely generous, worth more than five years of Giulio's salary. To answer the question of why the Grand Duke would pay a large dowry-not a wedding gift-on the occasion of the marriage of one of his singers, we must look into courtly politics and some rather curious business in Mantua.

In 1581 Vincenzo Gonzaga, Prince of Mantua, married Margherita Farnese, daughter of the governor of the low countries. ${ }^{19}$ But by 1583 there had been no children and the marriage was annulled on the grounds of nonconsumation, with each party accusing the other of a physical disability. Soon after the annullment negotiations were begun between the Mantuan and Florentine courts for a marriage between Vincenzo and Leonora de' Medici, but there was hanging over the young prince the suspicion that he was impotent and the Medici family hesitated. After some negotiations it was agreed that Vincenzo was to prove himself, and once it was obvious that he was capable of consumating a marriage he could marry Leonora. The question itself and the Medici insistence on proof became one of the most celebrated scandals of the time, and greatly embarrassed the Gonzaga family. ${ }^{20}$ Negotiations went on throughout the winter months of 1583-84, and it was finally agreed that the Medici family, through the Grand Duke's secretary Belisario Vinta, would select a young virgin as the means of that proof. The actual meeting between the Mantuan Prince and the Florentine virgin took place in Venice (neutral territory) in March, and was deemed a 
success. At the end of April that year Vincenzo married Leonora and two months later the Grand Duke offered 1,000 scudi to Giulio Caccini to marry the expectant Lucia. ${ }^{21}$

The evidence is not quite conclusive, but it would make some sense to believe that Pompeo was the child of Vincenzo Gonzaga and Lucia. A birthdate in 1584 would have made him sixteen at the time of the paternity suit-a bit young for marriage in our culture, but quite in keeping with his own times. That sixteen is not very old would also explain his fear of his father's displeasure. If my conclusion is correct, the references in the depositions to the magistrates' court are both technically wrong in their references to Pompeo's relationship to Giulio. He would certainly have been illegitimate, having been conceived out of wedlock by Lucia, but neither "figlio bastardo" nor "figlio naturale" is correct in reference to Giulio. But then perhaps there was no way to describe that rather peculiar relationship-as there is not at present. ${ }^{22}$

In any case, Pompeo must have been quite a talented young man both in music and in art. At the age of sixteen, in addition to singing in the second production of Peri's Euridice, he was already demonstrating sufficient teaching ability that the seasoned dramatists Corsi and Rinuccini would recommend him as a tutor for one of the roles in their presentation on a most important occasion. In addition, the testimony of the cleric Michele Dati indicates that at that age he was already producing paintings on commission, and the will of Jacopo Corsi indicates that a set of stools and a picture painted by Pompeo existed in that household before $1602 .^{23}$ Pompeo therefore practised not only his father's profession but that of his then-famous uncle, Giovanni Caccini, who was a noted sculptor and architect at the Medici court at the end of the sixteenth century.

Although his later career is little known to us, Pompeo apparently continued to distinguish himself in both music and art. A document from 1609 records that he sang a Christmas lauda written by Ottavio Rinuccini; ${ }^{24}$ an art work of his can be found in the Capella Strozzi in S. Trinita in Florence, along with two statues by his uncle; and a bust of Gabriello Chiabrera reported to have been in Genoa is signed by Pompeo and dated 1624. ${ }^{25}$ In 1620 he both designed the scenery for the opera L'Aretusa, favola in musica by Filippo Vitali and sang the role of Alfeo. ${ }^{26}$ On his versatility and musical competence we have his father's letter of 1611 to Piero Strozzi, recommending Pompeo for service in the Medici household and claiming that he is competent in music theory, plays chitarrone and is proficient at accompanying voices. ${ }^{27}$ Along with his half-sisters Francesca and Settimia, Pompeo obviously inherited a good measure of artistic talent from his 
mother Lucia Garglialanti. Encouraged and coached by his father and uncle, he developed into one of the more versatile members of the Caccini family.

If we should now cast our gaze somewhat wider, the story of Pompeo and his mother tells us a bit more about the social position of musicians. That musicians were of the servant class on into the twentieth century is a well-known fact. They had little money, usually less education, and were considered to be on a distinctly lower social plane than the wealthy throughout most of recorded history. But to reflect on the fate of Lucia Garglialanti in relation to what could be demanded of her by her royal masters gives a much harder focus to the concept of servant. There is no reason to suspect that this was an isolated event-Anthony Newcomb has documented a similar case in relation to Girolamo Frescobaldi from only a few years later. ${ }^{28}$ Gifted as some of the musicians of the court may have been, they were still subject to their noble employers in every way. As depressing as that realization may be, to realize that many of them rose to great artistic heights in spite of it is an encouraging monument to the resiliance and independence of the artistic spirit.

\section{Documents}

\section{Document I}

Sereniss[i]mo Gran Duca

Cammilla di Piero mazziere, nipote di Don Stefano Buonsignori, humilissima serva di V.S.A. povera con sei fanciulle, supplichevolmente recorrendo alle sue grazie gli espone qualmente disiderosa se li facessi giustizia del gran torto e disonore fattoli da Pompeo figliolo bastardo di Giulio Romano, perche' avendo bazzicato lungo tempo in sua casa, per insegnare cantare il prologo della comedia alla Ginevra detta l'Azzurrina sua figliola permettendoli tale bazzica detta supplicante per compiacere alli signori Giacopo Corsi et Ottavio Rinuccini, quali di cio' l' aveano richiesta a consignato detto giovane per insegnarla, con esperanza di acquistare la dote per maritarla e principalmente per servire la Cristianissima Reina i Francia e V.A.S. come era suo obligo, ebbe ardire un giorno appostando che la detta fanciulla fussi sola in casa, aprir l'uscio con chiave falsa ltro ferro, et facendoli violenza stuprarla et ingravidarla, il che tacque la detta supplicante perche' il giovane diede parola a' gentiluomini, fece scritta e promesse di torla per sua moglie, finita la comedia. Essendo poi stato ritenuto et sviato fuora da suo padre, acci 1 matrimonio non seguisse, fece ricorso al Magistrato degli Otto da' quali 
è stata data sentenza troppo piacevole e facile al giovane et non condegna di si' grave delitto avendolo condannato a scudi 75 solamente senza altra pena afflittiva essendo meritevole secondo li statuti di Firenze a legge comuni della galera. Pertanto ricorre ora a V.A.S. si degni farli giustizia, come suole a tutti, et non permetta che cosi' miseramente perda l'onore lei et le altre povere fanciulle ne che il suo fratello e cognato, non solita à far, ne à sopportar dishonore orto alcuno, se no consorecto per vie illecite rimediarvi, ne che essa supplicante, essendo di parenti honoratissimi quali han servito sempre fedeliss[imamen]te e al presente servono la sereniss[im]a casa de' Medici vedendoli à torto perdere di honore, ne appelli al suntuo tribunale ...27 feb. $1600[1601] .^{29}$

Francesco Buoninsegni

Florence Archivio di Stato (hereafter ASF), Otto di Guardia, Suppliche 2300 , \# 52

\section{Document II}

La Cammilla supplicante fece querela a Pompeo figliolo di Giulio Romano naturale, che praticando esso Pompeo in casa sua, con occasione che cantando la Ginevra sua figliola ancora di Musica andovi ad insegnarli il prologo della Comedia, et invaghitasi di detta Ginevra sotto pretesto di volerla per moglie un giorno entrasse in casa, non sendovi la madre, et con lusinghe e promesse e parte forza usasse con lei carnalmente che ne resto gravida; $e$ in contumacia il magistrato lo condann 1 di' 12 di febbraio 1600 [1601] per lo stupro in lire cento ed a dotare la Ginevra in scudi 75 , con condizione che pigliandola per moglie si intenda libero dalla detta dotazione; Hora parrendo alla madre che questa sente[nz]a non basta a recuperar l'honore toltoli, et alle promesse fatta, et desiderando che venghi e effettuato il parentado, domanda che se li dia tal castigo, che l'induca à osservare quanto ha promesso, se ne vorrà liberarse, et metterli tempo prefiss, in cancellaria il di 15 di Marzo 1600 [1601].

Buoninsegni primo d'aprile 1601

ASF. Otto di Guardia, Suppliche 2300, \# 52.

\section{Document III}

A di 12 di marzo 1600 [1601] in Firenze

Io Gian Jacopo Cini fo fede come questi mesi a dreto avendo bazzicato continuamente per conto della seta in casa di Mona Cammilla di Piero mazziere ho conosciuto lei e sue fanciulle onoratissime, e perche' vi ho veduto bazzicare del continuo Pompeo Caccini, per accertarmi della cagione la dimandai. La detta Mona Cammilla mi respose che venia perch dal Signor Jocomo Corsi e Signor Ottavio Rinuccini gli era stato ordinato che venisse per insegnar cantare il prologo della Comedia alla Ginevra sua figliola e 
ancora perch avea promesso e fatto in scritto di torla per moglie, finita la Comedia. E nel tempo delle nozze della Cristianissima reina di Francia avendo veduto nel dito della sopra detta Ginevra un anello con tre perle, dicendoli che non aveva serbatomi li confeti immaginandomi che l'avessi impalmata, mi rispose che glielo aveva fatto Pompeio, ma non che finita la Comedia avrei avuto le confezioni. Fo fede ancora come il medesimo ho inteso da bocca di esso Pompeo, il quale un giorno ragionando insieme nel gioco della Carda in Campaccio mi disse che per timore di suo padre, allora sdegnato contro esso Pompeo e la detta Ginevra perche' contro sua voglia recitava il prologo, e ancora per parecchiarsi più comodamente non potea sposarla, se non finita la comedia e per essere questa la verita arichiesta di detta mona Camilla ho fatto la presente di mia propria mano e volonta...

\section{Gia[n] iacomo Francescho Cini di Firenze}

ASF. Otto di Guardia, Suppliche 2300, \# 52

\section{Document IV}

Io Michele di Jacopo Date canonico fiorentino fo fede come più mesi sono Pompeo Caccini figliolo di Giulio Romano, con occasione che io andai a bottega del Cigoli, dove lavorava detto Pompeo, per sollecitarli due quadri di paesi che avea presi a farmi, mi preg he io volessi essere mezzano con madonna Camilla moglie di Piero mazziere che si contentassi di andare avanti ancora un anno o diciotto mesi senza scoprire il parentado che egli aveva fatto con lei della figliola, e questo per potere intanto avanzare de' suoi guadagni da potere fornirsi una camera, il che non gli potria riuscire ogni volta che da suo padre fussi mandato fuori di casa come gli avverrebbe come sapessi che egli avessi tolto moglie senza suo consenso; il che io feci con detta Madona Cammilla, la quale mi alleg olte ragioni per le quali non doveva ne' poteva aspettare queste tempo. Di che io so esser cosi' la verit, fo fede con questa di mia propria mano questo di' sopra in Firenze.

Michele Dati Con[oni]co dello Catted[rale] Fior[en]za sottoscritto 13 Marzo 1600 [1601]

ASF. Otto di Guardia, Suppliche 2300, \# 52.

\section{Document V}

26 Giu[gno] 1601

Ser[enissi]mo Gran Duca

Giulio Caccini humiliss[i]mo servit[o]re et Vassallo di V[ostra] A[Itezza] Ser[enissi]ma con ogni debita riverenza li espone come à i mesi passati fu condannato in contumacia del Magistrato de gli otto Pompeo suo figlio in pena di lire cento de gli otto applicate al Fisco et in Scudi settantacinque per depositarsi e pagarsi per Dote alla G[in]ev[r]a detta l'Azzurrina. Hora desiderando ripatriare detto suo figlio supplica à V.A. 
che gli voglia far gratia non ostante la contumacia, delle cento lire applicate al fisco essendo pronto nel resto di pagare li scudi settantacinque à detta Azzurrina ogni volta, che si mariterà conforme all' ordine del suddetto magistrato, che di tutto ne terrà perpetuo obbligo a VA. ser.ma per la quale pregherà sempre il N[ostro] Sig[no]re Dio che preservi felicissima

à messr Fr[ancis]co Boninsegni non ostand.

ASF. Otto di Guardia Suppliche 2300, \# 276

\section{Document VI}

... La Sig.ra Ginevra è stata ricevuta dala Maesta della Regina con dimostratione d'allegrenza, e di contento straordinario, e pur hoggi le ha' donato un bel para d'orecchini di diamanti ne cessa d' accarezzarla e favorirla. Il concerto di Giulio è piaciuto al Re talmente che la musica dur n' hora dopo mezza note e per cui inchinandomele umilm.te le prego dal Sig[no]re ogni felicità di Parigi li 13 di dicembre 1604.

Devotis[simament]e e humiliss[imament]e Vass[allo]

Ottavio Rinucc[ini]

ASF. Mediceo del Principato, Filza 5987, fol. 402

\section{Document VII}

Serenissima Gran Duchessa

Quando VA.S. parti di Fiorenze ella mi impose che io scrivessi a Mantova al signor Ottavio Rinuccini che facesse nuove scuse co quei principi sopra il non gli compiacere V.A.S. delle donne di Giulio Romano, parte per essere di già impiegate in queste feste di qui, parte per la poca robustezza di tutte, che viaggiando in tempo strano avian potuto patire e non servire nè là nè qu; e che se quelle Altezze volean accrescere il numero dei loro cantati che V.A. gli avrebbe mandato la Livia e la moglie di Pompeo, che non erano ancora impiegate e reggerebbano meglio al viaggio. Io scrissi subito come dovevo e ne ebbe risposta de' 19 di gen[naio] con queste parole a'punto: Offersi le cantatrice a offerta, e la scusa insieme della impossibilità di mandare le altre, dicalo a Madama, a ci appia che queste Altezze restano sodisfatte e che io ho fatto l'uffizio che io dovevo ... 5 feb[raio] 1607 [1608]

Camillo Rinuccini

ASF. Mediceo del Principato, Filza 5994

University of Toronto 


\section{Notes}

Note: I am grateful to the Social Sciences and Humanities Research Council of Canada for support of this research, and to Tim Carter, Dennis McAuliffe, Claude Palisca, Domenico Pietropaolo, and Barbara Sella for assistance.

1 Claude V. Palisca, "The First Performance of 'Euridice,'" Queens College Department of Music, Twenty-Fifth Annivensary Festschrift (1937-1962), ed. Albert Mell (New York: Queens College 1964), pp.1-23.

2 This seems to be a pun stemming from the colloquial use of "far mangiare i confetti" meaning "to celebrate a wedding." Cini was probably jokingly asking Ginevra why she had not saved herself for him.

3 Upon Jacopo Corsi's death in 1602, Giulio Caccini paid the estate a debt totalling just under 75 scudi (74.3.10 ducats). It is tempting to see a connection between this sum and the 75 scudi fee required of the Caccinis to be placed on deposit for the dowery. See Tim Carter, "Music and Patronage in Late Sixteenth-Century Florence: The Case of Jacopo Corsi (1561- 1602)," I Tatti Studies, Essays in the Renaissance 1 (Florence: I Tatti, 1985), n. 88. Knowledge of the details of Pompeo's paternity suit and of the possible fate of young sopranos may have weighed heavily in the 1603 decision of Vincenzo Gonzaga not to allow the young soprano Caterina Martinelli to stay in Florence at the house of Giulio Caccini in order to study voice. See Edmond Strainchamps, "The Life and Death of Caterina Martinelli: New Light on Monteverdi's 'Arianna," "Early Music History 5, ed. Iain Fenlon (Cambridge: Cambridge University Press, 1986), pp.155-86.

4 On the tradition of the Concerto delle donne in Ferrara, Mantua, Florence, and Rome, see Anthony Newcomb, The Madrigal at Ferrara, 1579-1597, 2 vols. (Princeton: Princeton Univ. Press, 1980).

5 Tim Carter, “A Florentine Wedding of 1608," Acta Musicologica, 55 (1983) 100. Carter also points out that there was another Pompeo at the Florence court, the lutenist Pompeo di Girolamo da Modena. Remo Giazotto, Le due patrie di Giulio Caccini (Florence: Leo S. Olschki, 1984), p.30, suggests that the part of Venus may have been played by Settimia Caccini, but there is no record of her having been in Mantua at that time while her name does appear on the list of performers for the performance scheduled to take place in Florence at the same time (see Carter, "Florentine Wedding," pp.105-07).

6 For details of the wedding and the performances, see Palisca, "First Performance."

7 After Palisca, "First Performance," pp.11-12, with additions.

8 For details see Palisca, Baroque Music (Englewood Cliffs, New Jersey: Prentice-Hall, Inc., 1968), p.30. For details of Peri's life see Tim Carter, "Jacopo Peri," Music and Letters 61 (1980), 121-35.

9 In two diary accounts of the performance only Emilio dei Cavalieri (a nobleman and Florentine ambassador) is mentioned in conjunction with the opera, and in one of them he is given credit as composer. See Antonio Solerti, Musica, ballo e drammatica alla Corte Medicea dal 1600 al 1637 (Florence: Benporad e Figlio, 1905), p.25.

10 Jacopo Peri, Euridice (Florence: Giorgio Marescotti, 1601). Facsimile (Rome: Reale Accademia d'Italia, 1934), and (Bologna: Libreria Editrice Forni, 1969). Modern edition, Howard Mayer Brown ed., Recent Researches in the Music of the Baroque Era, vols. 36, 37 (Madison, Wisconsin: A-R Editions, 1981). Translation of the Forward in Oliver Strunk, Source Readings in Music History: The Baroque Era (New York: W.W. Norton 1965), pp.13-16.

11 Giulio Caccini, Euridice (Florence: Giorgio Marescotti, 1600). Translation of the "Dedication" in Strunk, Source Readings, p.10. 


\section{8 / Renaissance and Reformation}

12 Giulio Caccini, Le Nuove Musiche (Florence: Marescotti, 1601 [1602]). Modern edition, H. Wiley Hitchcock. ed., Recent Researches in the Baroque Era (Madison, Wisconsin: A-R Editions, 1970). Translation of "Forward" in Strunk, Source Readings, pp.17-32.

13 See Howard M. Brown, "Music - How Opera Began: An Introduction to Jacopo Peri's Euridice (1600)," The Late Italian Renaissance, ed. Eric Cochrane (New York: Harper \& Row, 1970), pp.401-43. Brown refers to Caccini's setting as "the only 'spite opera' in the history of music" (p.421).

14 Documents for baptism of Settemia and Dianora discussed and published Maria Adelaide Bacherini Bartoli, "Giulio Caccini. Nuove fonti biografiche e lettere inedite," Studi Musicali 9 (1980) 62-3, 65.

15 It is given as "prima del 1588" in Enciclopedia dello spettacolo (Rome: Le Maschere, 1954), II, col. 1447-53; and Giazotto (Le due Patrie, p.29, n. 1) provides the date of 1578 without source. This of course would contradict the information below. I have not been able to trace any source for Giazotto's date.

16 ASF Depositeria generale Recasuti di Cassa no. 995.

17 Newcomb (The Madrigal, p.91) believes that the Concerto delle donne in Florence from as early as 1584 consisted of Vittoria Archilei, Laura Bovia, and Lucia Caccini. With the date of Lucia's marriage now established, her membership in this group from after June 1584 is probable.

18 Carter, "Jacopo Peri," p.124. These sums may not indicate their exact incomes. It is possible that Peri received other fees, and that Caccini's fee included that for his 'concerto delle donne.' I am indebted to Tim Carter for this caution.

19 Iain Fenlon, Music and Patronage in Sixteenth-century Mantua, 2 vols. (Cambridge: Cambridge UP, 1980), p.82.

20 Letters, documents, and memos relating the entire episode including the actual proof in clinical detail are preserved in ASF Mediceo, Filza 6354, and published in $n$ parentado fra la principessa Eleonora de' Medici e il principe Don Vicenzo Gonzaga é i Cimenti a cui fu costretto il detto Principe per attestare come egli fosse abile alla generazione (Firenze, 1886; rpt. Bologna: Forni, 1967).

21 In the published document cited in footnote 20 , secretary Vinta gives the name of the virgin only once, calling her Giulia: "Questo di 22 verso la sera in cocchio ho fatto venir la fanciulla in casa. Il nome è Giulia, è in 21 anno, è grande ... 22 febbraio 1584 [1584]." (p. 121). But in the introduction to the published documents the nineteenth-century editor (unnamed) states that in a diary by Susier there exists reference to the young girl, that she was taken to Florence and after giving birth became the wife of "un Giuliano, musico romano, con dote di tre mila scudi" (p. 6). With the rest of the facts provided here, it would seem probable that Vinta made a small mistake and that "Giulia" was "Lucia."

22 In the cast list for the second production of Peri's Euridice the singer of the part of Euridice is listed only as Caccini's sister-in-law. It is now possible to suggest a name for this role, Margherita Garglialanti, sister of Lucia. In his discussion of the cast for the 1589 Florentine intermedio, Iain Fenlon states that "Lucia Caccini performed... in the terzetti of Cavalieri's ballo together with her sister Margherita," (Music and Patronage, p.82). Although Lucia had died earlier and Giulio had remarried (to a woman also named Margherita), in 1600 Lucia's sister would still be his sister-in-law, and we do know that eleven years earlier she had sung in a public performance.

23 See Carter, "Music and Patronage," n. 55, 65.

24 "Con musica ecelente e doppo lo ufitio Ponpeo Caccini cant n musica una lauda della natività bellis[si]ma conposta dal Sig.re Ottavio Rinucini." ASF Compagnie religiose 
soppresse 162, no. 21, quoted in Edmond Strainchamps, "Marco da Gagliano and the Compagnia Dell'Arcangelo Raffaello in Florence: An Unknown Episode in the Composer's Life," Essays Presented to Myron P. Gilmore 2 Vols., ed. Sergio Bertelli and Gloria Ramakus (Florence: La Nuova Italia Editrice, 1978), II, 476, 486).

25 Dizionario biografico degli Italiani, vol. 16 (Rome: Enciclopedia Italiana, 1973), pp.34-5.

26 Enciclopedia dello spettacolo, col. 1452, and Bartoli, "Giulio Caccini," p.64.

27 Published in Bartoli "Giulio Caccini," pp.70-1.

28 "Girolamo Frescobaldi (1608-1615). A Documentary Study," Annales musicologiques 7 (1964-77), Société de Musique d'autrefois, pp.122-34.

29 The documents are dated according to the old calendar in which the year began on March 25. I have provided the modern date in square brackets. 